\title{
Cross-regulation of cortisol secretion by adrenocorticotropin and platelet-activating factor in perfused guinea pig adrenals
}

\author{
Toshio Shimada, Taeko Hirose, Itsuro Matsumoto and Tadaomi Aikawa \\ Department of Physiology, Nagasaki University School of Medicine, Nagasaki University Graduate School of Biomedical Sciences, 1-12-4 Sakamoto-machi, \\ Nagasaki 852-8523, Japan \\ (Correspondence should be addressed to T Shimada; Email: tshimada@net.nagasaki-u.ac.jp)
}

\begin{abstract}
We examined the cross-regulation of signaling between ACTHand platelet-activating factor (PAF)-mediated steroidogenesis in the perfused guinea pig adrenal gland. Our method of in situ perfusion using an artificial medium can evaluate whether cortisol secretion in response to ACTH and PAF is interactive. Treating adrenal glands with $100 \mathrm{pg} / \mathrm{ml}$ ACTH diminished the subsequent cortisol response to $10 \mathrm{nM}$ PAF. By contrast, PAF resulted in subsequent potentiation of ACTH-induced cortisol secretion. A mixture of $50 \mu \mathrm{M} \mathrm{L-} \alpha-1-$ oleoyl-2-acetyl-snglycerol (OAG), an activator of protein kinase $\mathrm{C}$ (PKC), and $3 \cdot 3 \mu \mathrm{M}$ calcium ionophore (A23187), or $10 \mu \mathrm{M}$ forskolin (FRK) diminished the cortisol response to PAF, whereas that to
\end{abstract}

ACTH was unaffected. Each of PAF, ACTH, or FRK eliminated the cortisol response to OAG plus A23187, whereas that to FRK was unaffected. These data show that the protein kinase A (PKA)-dependent processes activated by ACTH or FRK can interfere with PAF-induced signal transduction at receptor and post-receptor levels. In contrast, PKC-dependent processes activated by PAF promoted ACTH-signaling at receptor and post-receptor level. Cross-regulation between processes activated by PAF receptor-PKC and by ACTH receptor-PKA might function in the multifactorial regulation of adrenocortical steroidogenesis.

Journal of Endocrinology (2007) 195, 29-38

\section{Introduction}

Platelet-activating factor (PAF) is a potent mediator of immune and inflammatory responses, cardiovascular, reproductive, respiratory, metabolic, and nervous systems (Ishii \& Shimizu 2000, Stafforini et al. 2003). We found that $\mathrm{PAF}$ is a potent activator of glucocorticoid secretion from the adrenal glands of dogs (Aikawa et al. 1991) and guinea pigs (Shimada et al. 2005) perfused with artificial medium. In perfused guinea pig adrenals, PAF acts mainly through a membrane receptor accompanied by protein kinase $\mathrm{C}$ (PKC) activation (Shimada et al. 2005). On the other hand, ACTH acts through its receptor, melanocortin-2 receptor (Clark \& Cammas 1996), accompanied by protein kinase A (PKA) activation. The secretion of glucocorticoids in response to repeated infusions of adrenocorticotrophin (ACTH) or FRK is almost equal in perfused adrenal glands of dogs (Aikawa et al. 1986), mice (Yang et al. 1995), and guinea pigs (Shimada et al. 2005). By contrast, cortisol secretion in response to a second infusion of PAF was diminished (Shimada et al. 2005). Thus, PAF desensitizes steroidogenesis in a homologous manner through its own ligand. The mechanism of such receptor-specific homologous desensitization is agonistdependent phosphorylation of the receptor by specific G-protein-coupled receptor kinases (GRKs). Since a second exposure to the PKC activator, OAG, together with A23187 elicited a diminished response (Shimada et al. 2005), we proposed that not only GRKs but also activated PKC eliminates PAF receptor-mediated cortisol secretion. These processes should be associated with the modulation of the receptor and post-receptor compounds. At the receptor level, receptors would be phosphorylated and substantially uncouple from G-protein. At the post-receptor level, PKC or phospholipase C (PLC) might be directly inactivated.

The present study examines cross-regulation of adrenal corticosteroidogenesis by pathways activated by PAF and ACTH.

\section{Materials and Methods}

\section{Animals}

Adult male Hartley guinea pigs weighing 490-780 g each, were group housed in cages with suspended steel-mesh floors in a well-ventilated room at $25^{\circ} \mathrm{C}$ under a $12 \mathrm{~h}$ light: $12 \mathrm{~h}$ darkness cycle. Sterilized laboratory guinea pig chow and water were made available ad libitum. The protocols conformed to the guidelines governing animal experiments issued by the Animal Care and Use Committee of Nagasaki University and the Physiological Society of Japan Guiding Principles for the Care and Use of Animals in the Fields of Physiological Sciences (revised 2002). 


\section{Drugs and reagents}

We purchased 1-O-hexadecyl-2-acetyl-sn-glycero-3-phosphocholine (PAF) from Bachem (Bettendorf, Switzerland). Synthetic adrenocorticotropic hormone 1-24 (ACTH; Cortrosyn) was obtained from Organon (Boxtel, Holland). Forskolin (FRK) was purchased from Wako Pure Chemical Industries (Osaka, Japan) and L- $\alpha$-1-oleoyl-2-acetyl-sn-3glycerol (OAG) was obtained from Avanti Polar-Lipids (Alabaster, AL, USA.). BSA (fraction V) was obtained from Sigma. Krebs-Ringer bicarbonate glucose (KRBG) contained $121 \mathrm{mM} \mathrm{NaCl}, 2 \cdot 37 \mathrm{mM} \mathrm{KCl}, 1 \cdot 19 \mathrm{mM} \mathrm{MgSO} \cdot 7 \mathrm{H}_{2} \mathrm{O}$, $1 \cdot 19 \mathrm{mM} \quad \mathrm{KH}_{2} \mathrm{PO}_{4}, \quad 2 \cdot 54 \mathrm{mM} \quad \mathrm{CaCl}_{2} \cdot 2 \mathrm{H}_{2} \mathrm{O}, \quad 25 \mathrm{mM}$ $\mathrm{NaHCO}_{3}$ and $10 \mathrm{mM}$ glucose.

\section{Perfusion of adrenal glands}

The bilateral adrenal glands of guinea pigs were perfused in situ with fresh KRBG containing $0 \cdot 2 \%$ BSA and equilibrated with $95 \% \quad \mathrm{O}_{2}$ and $5 \% \quad \mathrm{CO}_{2}$ as described previously (Shimada et al. 2005). Briefly, the animals were anesthetized with an i.p. injection of pentobarbital sodium (Somnopentyl; 3.8 mg/100 g; Pitman-Moore, Washington Crossing, NJ, USA), and the abdomen was incised through the midline $10 \mathrm{~min}$ thereafter. The celiac, superior mesenteric, and inferior mesenteric arteries as well as the esophagus, vena portae, bile duct, and colon were ligated and resected. The animals were then eviscerated. The renal arteries and veins were ligated at the hilum of the kidney on both sides. We isolated the bilateral adrenal circulation by ligating the iliolumbar, subcostal, internal spermatic, and small vessels on both sides of the lumboabdominal region. The abdominal aorta and the inferior vena cava were separately ligated above the bifurcation and sutures were loosely passed around the aorta and inferior vena cava below the renal vessels. A cannula (i.v. catheter; ATOM, Tokyo, Japan) was inserted into the abdominal aorta. The top of the cannula was placed below the renal arteries and ligated. The cannula was connected to a silicon tube that was covered with a water jacket maintained at $38^{\circ} \mathrm{C}$ by circulating water (Thermo Minder; Taiyo, Saitama, Japan). The tube was attached to a mini-pump (SJ-1211; Atto, Tokyo, Japan) and connected to a large and smaller flask that contained KRBG plus $0 \cdot 2 \%$ BSA and test compounds dissolved in the same solution respectively. Both flasks were placed in a water bath maintained at $38{ }^{\circ} \mathrm{C}$ and bubbled with a gaseous mixture of $95 \% \mathrm{O}_{2}$ and $5 \% \mathrm{CO}_{2}$. One suture was loosely passed around the aorta below the diaphragm and another was passed around the inferior vena cava just above the right adrenal gland. Perfusion medium was introduced into the catheter in the abdominal aorta from the large flask via the mini-pump. Immediately after the aorta was ligated with the suture that had been passed around it below the diaphragm, the bilateral adrenal glands paled during perfusion with the medium. To stop the outflow from the lumbar arteries to the thoracic region, the muscles around the vertebral column were ligated together with the aorta and vertebral column by a suture at the crura of the diaphragm. Pentobarbital sodium ( $2 \mathrm{ml} ; 64.8 \mathrm{mg} / \mathrm{ml}$ ) was injected s.c. and we confirmed that the heartbeat had stopped. Another cannula was inserted into the hole in the inferior vena cava and ligated. Finally, the suture that had been passed around the inferior vena cava immediately above the right adrenal gland was ligated to direct the bilateral adrenal venous flow toward the exterior. The animal was placed in an acrylic chamber maintained at $38{ }^{\circ} \mathrm{C}$. During all experiments, the adrenal glands were perfused for $40 \mathrm{~min}$ to allow equilibration before the start of any procedures. Each of FRK, ACTH, PAF, or OAG plus A23187 was dissolved in $\mathrm{KRBG}$ containing $0 \cdot 2 \%$ BSA and perfused into the adrenal glands over a period of $5 \mathrm{~min}$ from the smaller flask. Fractions were collected for $5 \mathrm{~min}$ before and every $5 \mathrm{~min}$ after starting perfusion with ACTH and FRK or for $5 \mathrm{~min}$ before and every 2.5 or $5 \mathrm{~min}$ after starting PAF and OAG plus A23187.

Perfusates were collected into graduated glass tubes on ice, contaminating blood cells were removed by centrifugation, and the supernatant was extracted with methylene chloride.

The average weight of a pair of perfused adrenal glands was $266.4 \pm 4.5 \mathrm{mg}$ (means \pm s.E.M., $n=72$ ). The respective flow rates (mean \pm s.E.M., $n=6$ ): during the $5 \mathrm{~min}$ before and after perfusion with ACTH and FRK were ACTH $(100 \mathrm{pg} / \mathrm{ml})$, $1.84 \pm 0.13$ and $2.02 \pm 0.08 \mathrm{ml} / \mathrm{min}$; and FRK $(10 \mu \mathrm{M})$, $1 \cdot 84 \pm 0.07$ and $2 \cdot 02 \pm 0.11 \mathrm{ml} / \mathrm{min}$. The respective flow rates (mean \pm s.E.M., $n=6$ ): during the $5 \mathrm{~min}$ before and 2.5 min after perfusion with PAF and OAG plus A23187 were PAF (10 nM), 1.99 $\pm 0 \cdot 10$ and $2 \cdot 14 \pm 0.17 \mathrm{ml} / \mathrm{min} ; \mathrm{OAG}$ $(50 \mu \mathrm{M})$ plus A23187 $(3 \cdot 3 \mu \mathrm{M}), 1 \cdot 86 \pm 0 \cdot 12$ and $2 \cdot 07 \pm$ $0 \cdot 10 \mathrm{ml} / \mathrm{min}$.

\section{Biochemical analysis}

Perfusate extracts were purified by thin layer chromatography and then cortisol was quantified by fluorometry (Hirose 1977). We calculated the secretion rate of cortisol (ng/100 mg adrenal weight per min) by multiplying the concentration of the steroid $(\mathrm{ng} / \mathrm{ml})$ with the adrenal flow $(\mathrm{ml} / \mathrm{min})$ per $100 \mathrm{mg}$ adrenals. We calculated the total secretion of cortisol during the 30- or 15-min after starting perfusion with ACTH, FRK, PAF, or OAG plus A23187 over the basal value (immediately before infusion of compounds).

\section{Statistical analysis}

Results are expressed as means \pm s.E.M. Data were analyzed using STATISTICA software (Stat Soft, Tulsa, OK, USA). Mean secretory rates during each period and the secretion of cortisol were statistically compared by one-way or two-way ANOVA, followed by the Newman-Keuls post hoc test for multiple comparisons. Student's $t$-test (two-tailed) for paired data compared sets of two values. Statistical significance was established at $P<0 \cdot 05$. 


\section{Results}

Secretory response of cortisol to $A C T H$ and $P A F$ after exposure to $P A F$ and $A C T H$ respectively

To study the effect of ACTH and PAF cross-regulation on the secretory response of cortisol in the perfused guinea pig adrenal, $10 \mathrm{nM}$ PAF was perfused for $45-50 \mathrm{~min}$ before $100 \mathrm{pg} / \mathrm{ml}$ ACTH (Fig. 1A). We also similarly examined the cortisol response to PAF after ACTH perfusion (Fig. 1B). As the cortisol response to ACTH after saline infusion (vehicle control) was almost equal to the response to first and second infusions of repeated exposure to $\mathrm{ACTH}$, we compared the response to second infusions of ACTH (Fig. 1B) with the first one (Fig. 1A). Exposure to PAF potently augmented subsequent cortisol release in response to $\mathrm{ACTH}$; the rate of maximal cortisol secretion induced by the second perfusion with ACTH was significantly augmented (Fig. 1A). By contrast, ACTH attenuated subsequent cortisol release in response to PAF; the rate of maximal cortisol secretion induced by the second PAF infusion was significantly attenuated (Fig. 1B). The total amounts of cortisol secretion in response to the second perfusions with ACTH and PAF were $162 \cdot 8$ and $40 \cdot 9 \%$ when compared with the initial responses (Fig. 1C and Table 1). Thus, PAF augmented ACTH-mediated cortisol secretion, and ACTH diminished PAF-mediated cortisol secretion.

Secretory responses of cortisol to PAF and FRK after perfusion with FRK and $P A F$ respectively

To determine whether PKA participates in the crossregulation of cortisol secretion by $\mathrm{ACTH}$ and PAF, FRK, an activator of cAMP-PKA pathways, was perfused before PAF (Fig. 2A). Cortisol secretion induced by $10 \mathrm{nM}$ PAF after perfusion with $10 \mu \mathrm{M}$ FRK resulted in potent suppression. The total amount of cortisol secretion in response to the second perfusions with PAF was $15.9 \%$ when compared with the initial responses (Fig. 2C). On the contrary, PAF potently augmented subsequent
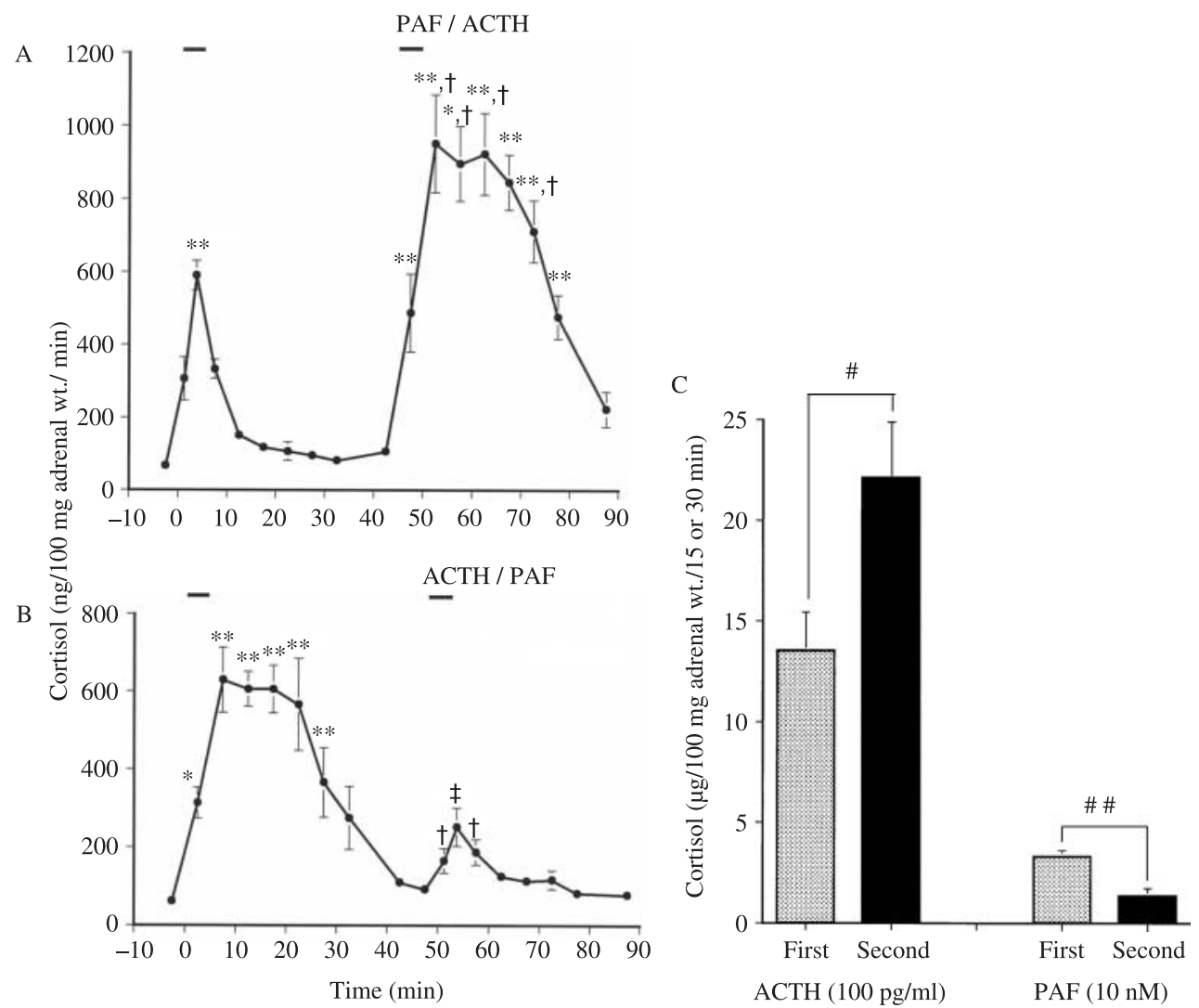

Figure 1 Effect of PAF on ACTH-induced cortisol secretion and vice versa. (A) We perfused adrenals with $10 \mathrm{nM}$ PAF for $5 \mathrm{~min}$ (bar above curve) then with $100 \mathrm{pg} / \mathrm{ml} \mathrm{ACTH}$ for $5 \mathrm{~min}$ (bar above curve), and monitored cortisol production. (B) Adrenals were perfused with $100 \mathrm{pg} / \mathrm{ml} \mathrm{ACTH}$ followed by $10 \mathrm{nM}$ PAF and cortisol secretion was monitored. (C) Total amounts of cortisol secretion during first and second perfusions with ACTH and PAF were as follows: $13 \cdot 6 \pm 1 \cdot 9$ and ${ }^{\#} 22 \cdot 1 \pm 2 \cdot 8(\mu \mathrm{g} / 100 \mathrm{mg}$ adrenal wt./30 min) for ACTH, and $3 \cdot 3 \pm 0 \cdot 3$ and $^{\# \#} 1 \cdot 4 \pm 0 \cdot 4$ ( $\mu \mathrm{g} / 100 \mathrm{mg}$ adrenal wt. $\left./ 15 \mathrm{~min}\right)$ for PAF. All data are shown as means \pm s.E.M. $(n=6)$.

${ }^{* *} P<0 \cdot 01,{ }^{*} P<0.05$ versus basal value (immediately before perfusion with compounds); ${ }^{\ddagger} P<0 \cdot 01,{ }^{+} P<0 \cdot 05$ and ${ }^{\sharp} P<0 \cdot 01,{ }^{\sharp} P<0.05$ first versus second perfusion. 
Table 1 Summary of experimental results

\begin{tabular}{|c|c|c|c|c|}
\hline & \multicolumn{4}{|c|}{ Second application } \\
\hline & PAF & ACTH & $\begin{array}{l}\text { OAG }+ \\
\quad \text { A23187 }\end{array}$ & Forskolin \\
\hline \multicolumn{5}{|l|}{ First application } \\
\hline PAF & $\downarrow \downarrow$ & $\uparrow \uparrow \uparrow$ & $\downarrow$ & $\uparrow \uparrow$ \\
\hline ACTH & $\downarrow \downarrow$ & - & $\downarrow$ & - \\
\hline $\mathrm{OAG}+\mathrm{A} 23187$ & $\downarrow \downarrow \downarrow$ & $\uparrow$ & $\downarrow \downarrow \downarrow$ & - \\
\hline Forskolin & $\downarrow \downarrow \downarrow$ & - & $\downarrow$ & - \\
\hline
\end{tabular}

$\downarrow, \uparrow$, or - indicates a decrease, increase, or no change respectively, in the total amounts of cortisol secretion in response to second application of $10 \mathrm{nM}$ PAF, $100 \mathrm{pg} / \mathrm{ml}$ ACTH, $50 \mu \mathrm{M}$ OAG plus $3 \cdot 3 \mu \mathrm{M} \mathrm{A23187}$, and $10 \mu \mathrm{M}$ FRK when compared with those of first applications.

cortisol release in response to FRK (Fig. 2B), and the rate of sub-maximal cortisol secretion induced by the second perfusion with FRK was potently augmented. PAF caused a consistent, but not statistically significant, augmentation in the total amounts of cortisol secretion in response to the second perfusion with FRK (Fig. 2C). Thus, PAF augmented FRK-mediated cortisol secretion, and PKA activated by FRK participates in heterologous desensitization of PAF-induced cortisol secretion.
Secretory response of cortisol to $A C T H$ after perfusion with $O A G$ plus $A 23187$ and vice versa

To confirm whether PKC participates in the cross-regulation of cortisol secretion by ACTH and PAF, OAG plus A23187, a direct PKC activator, was perfused before ACTH (Fig. 3A). The cortisol response to $100 \mathrm{pg} / \mathrm{ml}$ ACTH after $50 \mu \mathrm{M}$ OAG plus $3 \cdot 3 \mu \mathrm{M}$ A23187 was unaffected. By contrast, ACTH potently attenuated subsequent cortisol release in response to OAG plus A23187 (Fig. 3B). The total amounts of cortisol secretion in response to the second perfusions with $\mathrm{ACTH}$ and OAG plus A23187 were $119 \cdot 7$ and $47 \cdot 0 \%$ respectively, when compared with the initial responses (Fig. 3C and Table 1). Thus, ACTH-mediated activation of PKA diminishes the OAG plus A23187-induced cortisol secretion, and PKC activated by OAG plus A23187 did not significantly affect ACTH-mediated one.

Secretory response of cortisol to OAG plus A23187 after prior perfusion with FRK and vice versa

To confirm cross-regulation of post-receptor second messenger-dependent kinases, OAG plus A23187 was perfused before FRK (Fig. 4A). The cortisol response to
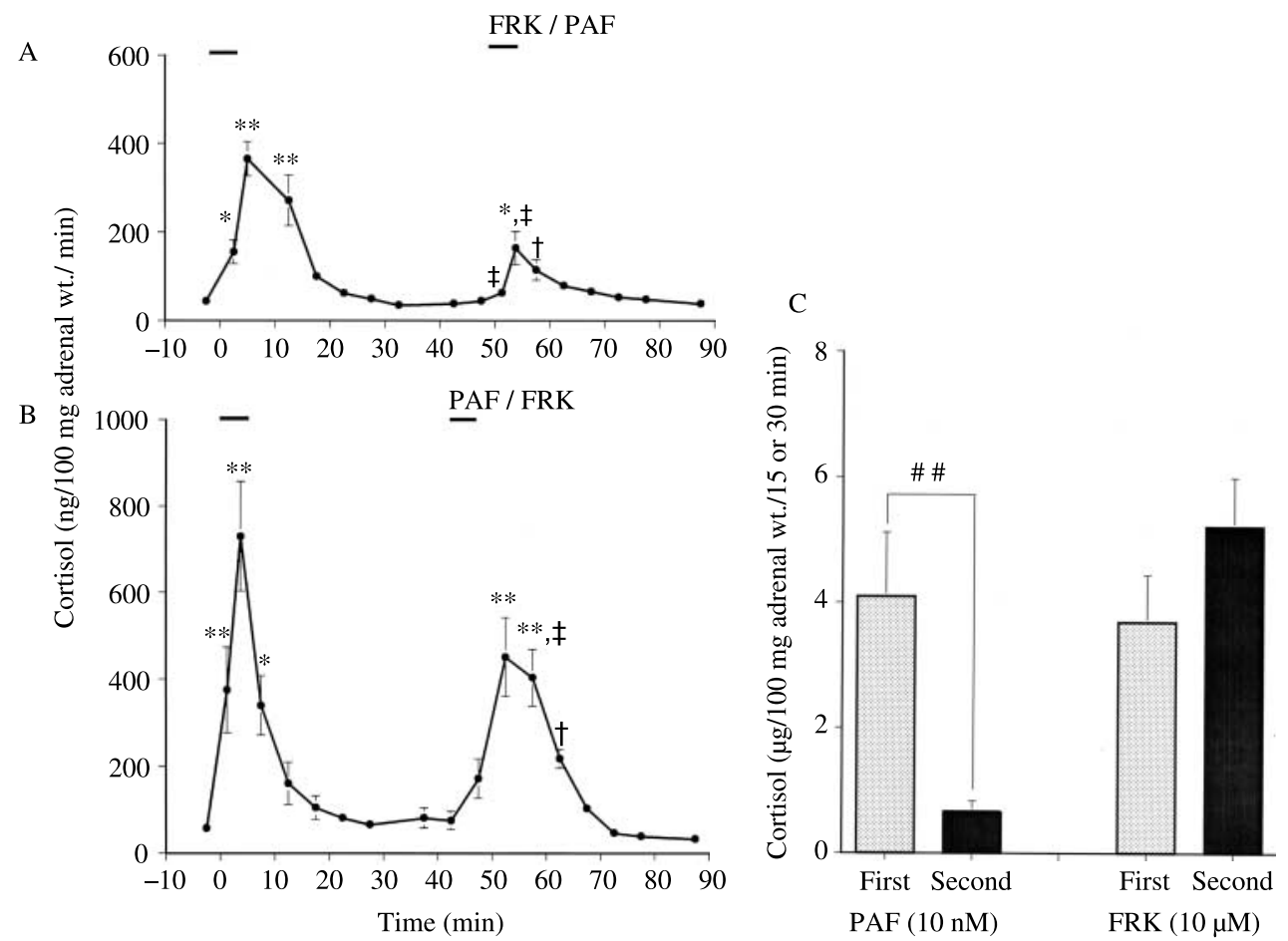

Figure 2 Effect of FRK on PAF-induced cortisol secretion and vice versa. (A) Adrenals were perfused with $10 \mu \mathrm{M}$ FRK for $5 \mathrm{~min}$ (bar above curve) followed by $10 \mathrm{nM}$ PAF for $5 \mathrm{~min}$ (bar above curve), and cortisol secretion was monitored. (B) Adrenals were perfused with $10 \mathrm{nM}$ PAF followed by $10 \mu \mathrm{M} \mathrm{FRK}$, and cortisol production was monitored. (C) Total amounts of cortisol secretion during first and second perfusions with PAF and FRK were as follows: $4 \cdot 1 \pm 1 \cdot 9$ and ${ }^{\# \#} 0 \cdot 7 \pm 0 \cdot 2(\mu \mathrm{g} / 100 \mathrm{mg}$ adrenal wt./15 min) for PAF, and $3 \cdot 7 \pm 0 \cdot 7$ and $5 \cdot 2 \pm 0 \cdot 8(\mu \mathrm{g} / 100 \mathrm{mg}$ adrenal wt./30 min) for FRK. All data are shown as means \pm s.E.M. $(n=6)$. For significance of differences, see Fig. 1. 

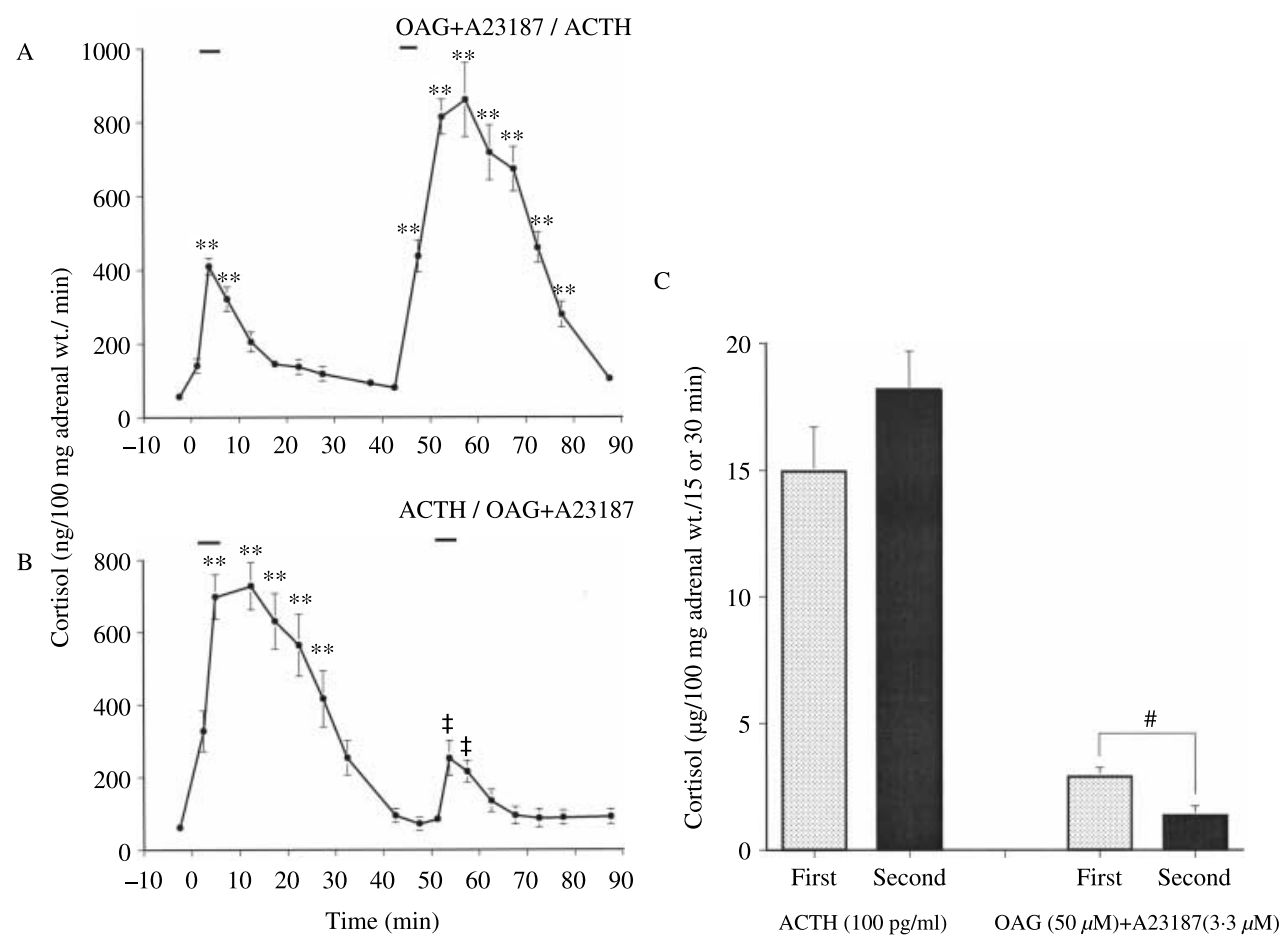

Figure 3 Effect of OAG plus A23187 on ACTH-induced cortisol secretion and vice versa. (A) Adrenals were perfused with $50 \mu \mathrm{M}$ OAG plus $3.3 \mu \mathrm{M} \mathrm{A} 23187$ for $5 \mathrm{~min}$ (bar above curve) followed by $100 \mathrm{pg} / \mathrm{ml}$ ACTH for $5 \mathrm{~min}$ (bar above curve), and cortisol secretion was monitored. (B) Adrenals were perfused with $100 \mathrm{pg} / \mathrm{ml}$

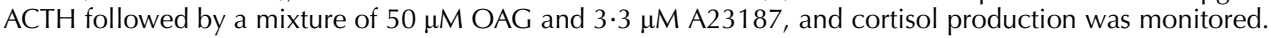
(C) Total amounts of cortisol secretion during first and second perfusions with ACTH and OAG plus A23187 were as follows: $15 \cdot 0 \pm 1 \cdot 6$ and $18 \cdot 2 \pm 1 \cdot 5(\mu \mathrm{g} / 100 \mathrm{mg}$ adrenal wt./30 min) for ACTH, and $2.9 \pm 0 \cdot 4$ and ${ }^{\#} 1 \cdot 4 \pm 0 \cdot 3$ ( $\mu \mathrm{g} / 100 \mathrm{mg}$ adrenal wt./15 min) for OAG plus A23187. All data are shown as means \pm s.E.M. $(n=6)$. For significance of differences, see Fig. 1.

$10 \mu \mathrm{M}$ FRK after $50 \mu \mathrm{M}$ OAG plus $3 \cdot 3 \mu \mathrm{M}$ A23187 was unaffected. By contrast, the cortisol response to OAG plus A23187 after FRK was diminished (Fig. 4B). The total amounts of cortisol in response to the second perfusions with FRK and OAG plus A23187 were $109 \cdot 9$ and $57 \cdot 1 \%$ when compared with the initial responses (Fig. 4C; Table 1). Thus, PKA activated by FRK diminished OAG plus A23187induced cortisol secretion, but PKC activated by OAG plus A23187 did not affect the FRK-activated one.

\section{Secretory response of cortisol to ACTH after FRK and} vice versa

To confirm whether PKA affects ACTH-induced cortisol secretion, FRK was perfused before ACTH (Fig. 5A). The cortisol response to $100 \mathrm{pg} / \mathrm{ml}$ ACTH after $10 \mu \mathrm{M}$ FRK was unaffected. Similarly, ACTH did not affect subsequent cortisol release in response to FRK (Fig. 5B). The total amounts of cortisol in response to the second perfusions with ACTH and FRK were $79 \cdot 7$ and $104 \cdot 2 \%$ respectively, of the initial responses (Fig. 5C; Table 1). Thus, the ACTH receptor-cAMP-PKA pathway is almost completely free of desensitization.
Secretory response of cortisol to PAF after OAG plus A23187 and vice versa

To confirm whether PKC plays an essential role in PAF desensitization, OAG plus A23187 was perfused before PAF (Fig. 6A). The cortisol response to $10 \mathrm{nM}$ PAF after $50 \mu \mathrm{M}$ OAG plus $3 \cdot 3 \mu \mathrm{M}$ A23187 was obviously attenuated. Similarly, PAF also attenuated the subsequent cortisol release in response to OAG plus A23187 (Fig. 6B). The total amounts of cortisol released in response to the second perfusions with PAF and OAG plus A23187 were $29 \cdot 7$ and $52.7 \%$ respectively of the initial responses (Fig. 6C and Table 1). Activated PKC induces heterologous desensitization of the PAF-activated cortisol secretion, and PAF-mediated activation of PKC down-regulates the OAG plus A23187activated one.

\section{Discussion}

This study characterizes the functional properties of the short-term cross-regulation of PAF- and ACTH-mediated cortisol secretion using in situ perfusion of the guinea pig 

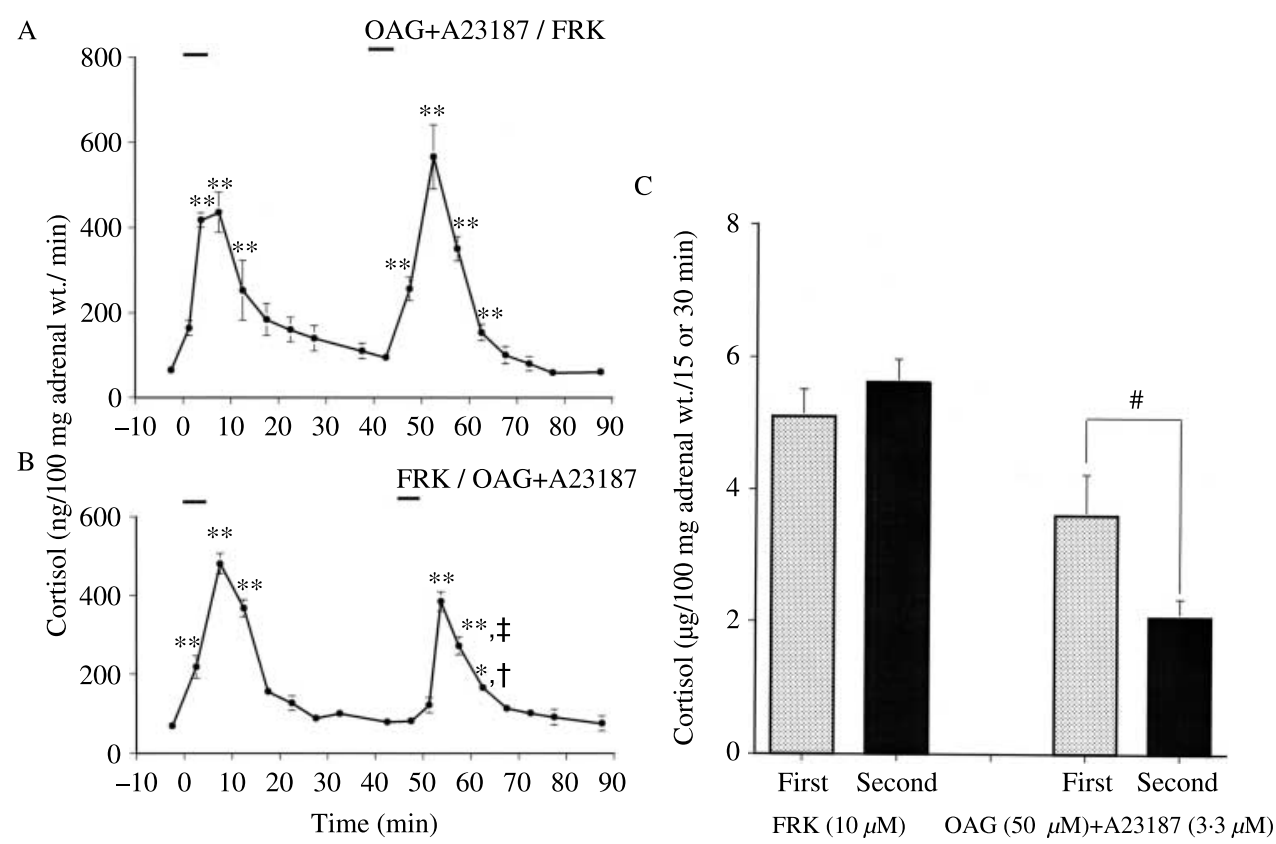

Figure 4 Effect of OAG plus A23187 on FRK-induced cortisol secretion and vice versa. (A) Adrenals were perfused with a mixture of $50 \mu \mathrm{M}$ OAG plus $3 \cdot 3 \mu \mathrm{M} \mathrm{A} 23187$ for $5 \mathrm{~min}$ (bar above curve) followed by $10 \mu \mathrm{M}$ FRK for $5 \mathrm{~min}$ (bar above curve), and cortisol secretion was monitored. (B) Adrenals were perfused with $10 \mu \mathrm{M}$ FRK followed by $50 \mu \mathrm{M}$ OAG plus $3 \cdot 3 \mu \mathrm{M} \mathrm{A} 23187$ and cortisol secretion was monitored. (C) Total amounts of cortisol secretion during first and second perfusions with FRK and OAG plus A23187 were as follows: $5 \cdot 1 \pm 0 \cdot 4$ and $5 \cdot 6 \pm 0 \cdot 4$ $\left(\mu \mathrm{g} / 100 \mathrm{mg}\right.$ adrenal wt./30 min) for FRK, and $3 \cdot 6 \pm 0 \cdot 6$ and $^{\#} 2 \cdot 1 \pm 0 \cdot 3(\mu \mathrm{g} / 100 \mathrm{mg}$ adrenal wt./15 min) for OAG plus A23187. All data are shown as means \pm s.E.M. $(n=6)$. For significance of differences, see Fig. 1 .

adrenal gland. The PAF receptor interacts with multiple G-proteins, $G_{\mathrm{q} / 11}$ and $G_{i}$, leading to the simultaneous stimulation of distinct signaling pathways. While the ACTH receptor interacts preferentially with stimulatory G-protein $\left(\mathrm{G}_{\mathrm{s}}\right)$ to stimulate adenylyl cyclase (AC), coupling to inhibitory G-protein $\left(\mathrm{G}_{\mathrm{i}}\right)$ has also been reported (Cote et al. 2001, Martini et al. 2004). However, the net effect of $\mathrm{G}_{\mathrm{i}}$ activation is the stimulation of cAMP production via the $\beta \gamma$-subunit of $G_{i}$ and not AC inhibition through the $\alpha_{i}$ subunit (Cote et al. 2001).

Prior perfusion with PAF preferentially enhanced cortisol secretion in response to ACTH (Fig. 1A). Angiotensin II (ANG II) and ACTH are major hormonal regulators of the adrenal zona glomerulosa and zona fasciculata. In adrenal glomerulosa and fasciculata cells, ANG II enhances subsequent ACTH-induced AC activity and the steroidogenic response (Langlois et al. 1992, Baukal et al. 1994). Since the actions of PAF and ANG II are mediated by PKC activation, we evaluated the effects of an activator of the PKC pathway on the cortisol response to ACTH. OAG plus A23187 did not significantly augment the subsequent cortisol response to ACTH (Fig. 3A). This means that direct PKC activation cannot mimic the potentiating effect of PAF. This finding suggests that $G_{q / 11}$ activation by PAF binding to the receptor is required for potent augmentation of the cortisol response to ACTH. Although ANG II potentiates the stimulatory effect of ACTH in glomerulosa cells, the PKC activator, phorbol 12-myristate 13-acetate (PMA), only partially mimics the effect of ANG II (Langlois et al. 1992). Besides, these actions of ANG II and PMA are prevented by pre-incubation with calcineurin $\left(\mathrm{Ca}^{2+} /\right.$ calmodulin-dependent protein phosphatase) inhibitors (Baukal et al. 1994). The dual regulation system mediated by $\mathrm{Ca}^{2+}$-calmodulin and PKC might explain why ACTH-induced cortisol secretion can be regulated through phosphorylation and dephosphorylation steps that control the activities of ACTH receptor-coupled G-proteins and/or AC. Figs $2 \mathrm{~B}$ and $4 \mathrm{~A}$ show that PAF significantly augmented but OAG plus A23187 did not affect the cortisol response to FRK. Two sites of enhancement of ACTH receptor-mediated signaling should be considered. One is at the receptor and/or G-protein level, namely, a result of greater turnover of $G_{s}$ or attenuation of $\alpha_{i}$ subunit of $G_{i}$ that renders receptors resistant to inactivation and the other is the potentiation of AC activity. The results indicate that PKC-dependent processes activated by PAF promote ACTH signaling at receptor and post-receptor levels.

Our previous results have indicated that the secretory response of cortisol to repeated infusions of ACTH (Aikawa et al. 1986, Yang et al. 1995, Shimada et al. 2005) or FRK (Shimada et al. 2005) is almost equal (Table 1). The results suggest that either desensitizing or potentiating regulation is absent in PKA-induced 

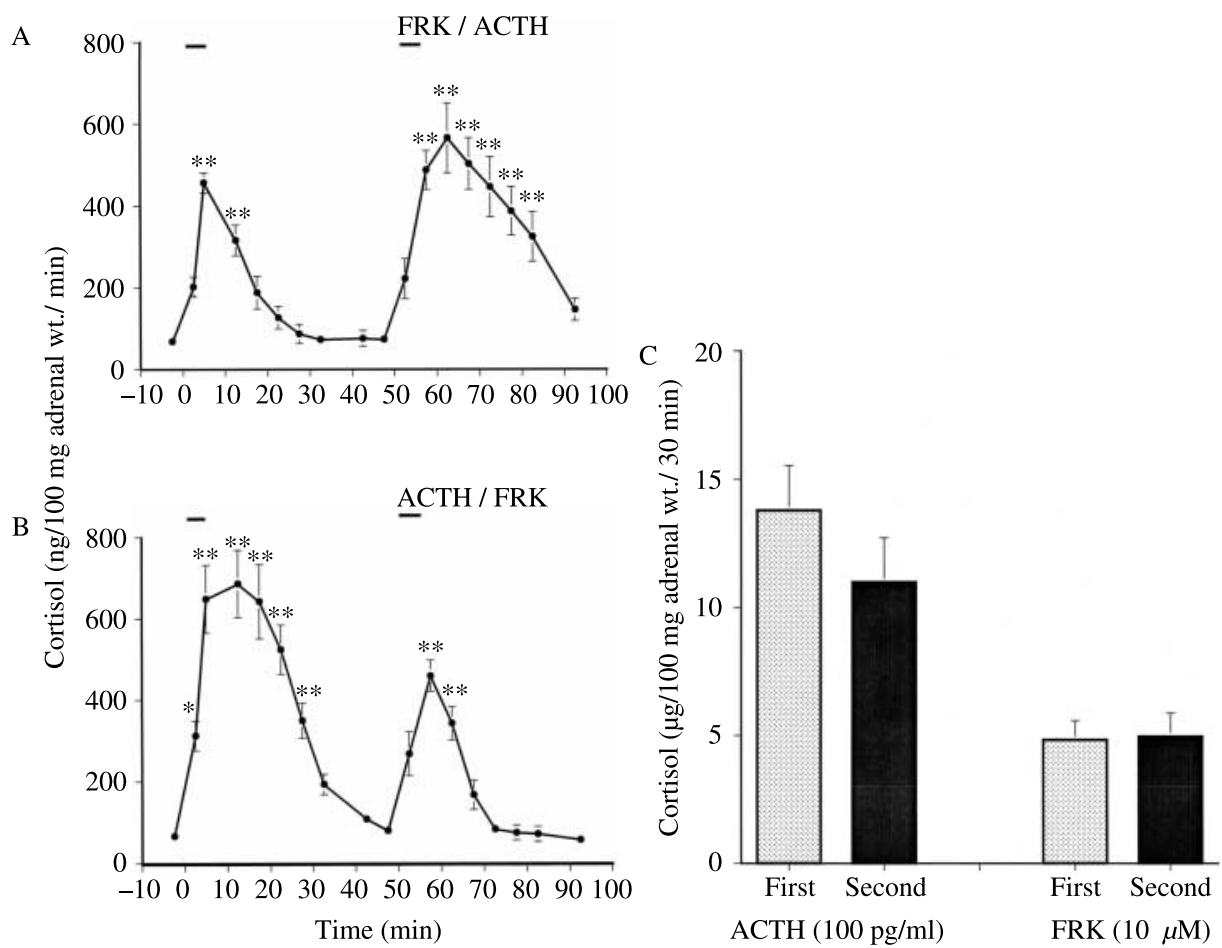

Figure 5 Effect of FRK on ACTH-induced cortisol secretion and vice versa. (A) Adrenals were perfused with $10 \mu \mathrm{M}$ FRK for $5 \mathrm{~min}$ (bar above curve) followed by $100 \mathrm{pg} / \mathrm{ml}$ ACTH for $5 \mathrm{~min}$ (bar above curve) and cortisol secretion was monitored. (B) Adrenals were perfused with $100 \mathrm{pg} / \mathrm{ml} \mathrm{ACTH}$ followed by $10 \mu \mathrm{M} \mathrm{FRK}$, and cortisol production was monitored. (C) Total amounts of cortisol secretion during first and second perfusions with ACTH and FRK were as follows: $13 \cdot 8 \pm 1 \cdot 7$ and $11 \cdot 0 \pm 1 \cdot 7(\mu \mathrm{g} / 100 \mathrm{mg}$ adrenal wt./30 min) for ACTH, and $4 \cdot 8 \pm 0 \cdot 8$ and $5 \cdot 0 \pm 0 \cdot 9$ $(\mu \mathrm{g} / 100 \mathrm{mg}$ adrenal wt./30 $\mathrm{min})$ for FRK. All data are shown as means \pm s.E.M. $(n=6)$. For significance of differences, see Fig. 1.

steroidogenesis. However, short- and long-term incubations with ACTH have generated contradictory results in terms of regulation of the numbers of $\mathrm{ACTH}$ receptors and the production of glucocorticoids. Some investigators have found up-regulation (Penhoat et al. 1989, Lebrethon et al. 1994), whereas others have found down-regulation or no effect (Sheela Rani et al. 1983, Lamberts et al. 1987, Kilianova et al. 2006). To verify the effect of activated PKA on ACTH-induced cortisol secretion, we perfused adrenal glands with FRK and found that the subsequent cortisol response to ACTH was unaffected (Fig. 5A). Although the ACTH receptor has potential sites for phosphorylation by PKC and PKA in the second and/or third cytoplasmic loops (Clark \& Cammas 1996), such sites might not be correlated with susceptibility to desensitization or potentiation.

Within seconds or minutes of PAF challenge, cells can diminish or virtually eliminate agonist-evoked responses. Such desensitization involves phosphorylation of the receptors on one or more intracellular domains and the uncoupling of receptors from signal-transducing G-proteins. Short-term desensitization of receptors can be either homologous or heterologous. The former is restricted to the agonist-occupied form of the receptor, being mediated through phosphorylation by GRK (Chuang et al. 1992). We indicated that repeated PAF infusion desensitizes cortisol secretion in response to PAF in a homologous manner (Shimada et al. 2005). Heterologous desensitization occurs independently of receptor binding by a ligand and is mediated through phosphorylation by activated PKC and/or PKA. Agonists that target different receptors or exposure to desensitizing compounds induce this type of desensitization. These phosphorylation phenomena promote the binding of an arrestin to receptors, which prevents subsequent coupling of the receptor to the G-protein. Both homologous and heterologous types of desensitization are adaptive physiological processes that terminate hyper-responsiveness. After $30 \mathrm{~min}$ to several hours of exposure to an agonist, short-term desensitization is augmented by internalization of a plasma membrane receptor into intracellular vesicles, and the receptors become down-regulated (Ferguson 2001).

Cross-desensitization among receptors for PAF and peptide chemoattractants ( $N$-formylpeptide, a cleavage product of the fifth component of complement (C5a) and interleukin-8) demonstrated that although the response to PAF was cross-desensitized by these peptide ligands, PAF did not cross-desensitize the responses to any of the peptide chemoattractants. The cross-desensitization of PAF receptor 

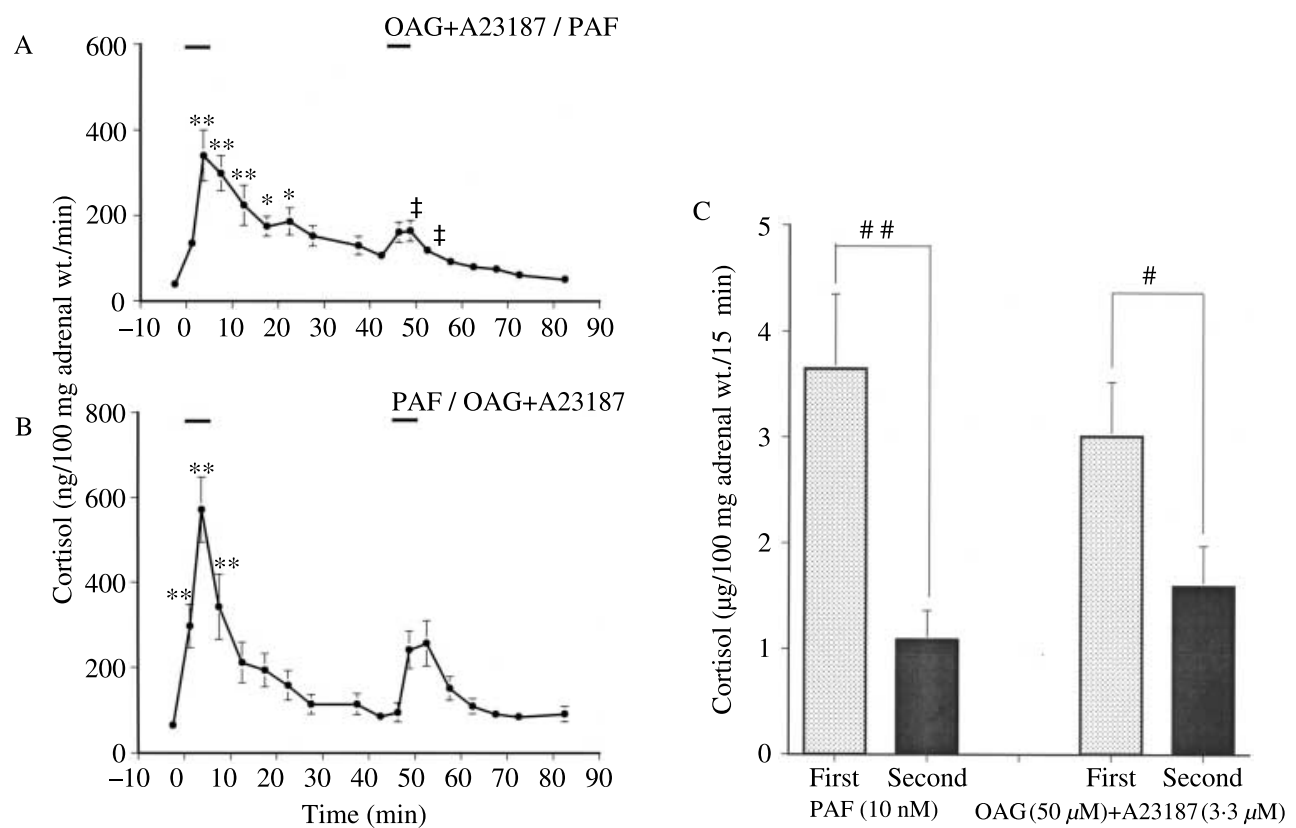

Figure 6 Effect of OAG plus A23187 on PAF-induced cortisol secretion and vice versa. (A) Adrenals were perfused with $50 \mu \mathrm{M}$ OAG plus $3.3 \mu \mathrm{M}$ A23187 for 5 min (bar above curve) followed by $10 \mathrm{nM}$ PAF for 5 min (bar above curve), and cortisol secretion was monitored. (B) Adrenals were perfused with $10 \mathrm{nM}$ PAF followed by $50 \mu \mathrm{M}$ OAG and $3 \cdot 3 \mu \mathrm{M} \mathrm{A23187}$, and cortisol production was monitored. (C) Total amounts of cortisol secretion during first and second perfusions with PAF and OAG plus A23187 were as follows: $3 \cdot 7 \pm 0 \cdot 7$ and ${ }^{\# \#} 1 \cdot 1 \pm 0 \cdot 3(\mu \mathrm{g} / 100 \mathrm{mg}$ adrenal

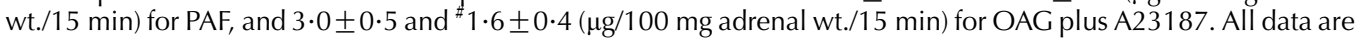
shown as means \pm s.E.M. $(n=6)$. For significance of differences, see Fig. 1.

induced by peptide chemoattractants was a consequence of PAF receptor cross-phosphorylation (Tomhave et al. 1994, Richardson et al. 1996). We found that ACTH preferentially attenuated the cortisol response to subsequent PAF exposure (Fig. 1B). Prior ACTH exposure interferes with ANG II-induced signaling and aldosterone production in adrenal glomerulosa cells (Yoshida et al. 1991). Since the action of ACTH is mediated by PKA activation, heterologous desensitization of PAF and ANG II receptors by PKA might be involved in desensitization of the adrenal fasciculata and glomerulosa cells. Therefore, we evaluated the effects of an activator of the CAMP-PKA pathway and found that prior perfusion with FRK significantly inhibited the cortisol response to PAF (Fig. 2A). Prior incubation with cAMP also interferes with the signaling pathway of ANG II in adrenal glomerulosa cells (Yoshida et al. 1991). These results indicate that PKA plays a pivotal role in heterologous desensitization of PAF and ANG II receptors. In contrast to numerous agonist-dependent and -independent PKC phosphorylation sites, the cytoplasmic tail of the human PAF receptor has only one consensus sequence for PKA phosphorylation (Kennelly \& Krebs 1991). While differences in phosphorylation sites might be correlated with the difference in susceptibility to desensitization, such sites should play a pivotal role in cross-desensitization. Moreover, ACTH or FRK attenuated the subsequent cortisol response to OAG plus A23187 (Figs 3B and 4B). This evidence indicates that the PKA-dependent processes activated by ACTH or FRK can interfere with PAF signal transduction at the receptor and post-receptor levels.

We clarified the effect of OAG plus A23187 on the cortisol response to PAF. Prior perfusion with OAG plus A23187 preferentially attenuated the cortisol response to PAF (Fig. 6A), indicating that PKC plays a pivotal role in PAF receptor desensitization. Likewise, PKC activators inhibit PAF binding and signaling (Schwertschlag \& Whorton 1988, Yamazaki et al. 1989, Ali et al. 1994). These results suggest that at least three kinases (most likely PKA, PKC, and GRKs) phosphorylate and desensitize PAF receptors. The other two sites of interference in PAF receptor-mediated signaling are at the PLC and PKC levels. In RBL-2H3 cells that express the PAF receptor, PKC but not PKA phosphorylates PLC $\beta_{3}$, resulting in the attenuation of responses stimulated by PAF (Ali et al. 1997). We found that since the cortisol response to OAG plus A23187 was attenuated by prior exposure to PAF (Fig. 6B) or this mixture (Shimada et al. 2005; Table 1), the membrane-associated form of PKC might be readily degraded by proteolysis (Kishimoto et al. 1989).

The most fundamental issue is the physiological significance of PAF and ACTH cross-regulation in the adrenal fasciculata. Under physiological conditions, sub-nanomolar or nanomolar concentrations of PAF circulate in the 
peripheral blood of humans, rabbits, and rats (Caramelo et al. 1984). The blood PAF level increases during endotoxic shock, sepsis, asthma, inflammation, and anaphylaxis (Ishii \& Shimizu 2000). Adrenocortical cells can produce and have high-affinity site for PAF (Pelosin et al. 1991). Furthermore, i.v. and i.c.v. injections of PAF induce ACTH secretion (Bernardini et al. 1989, Rougeot et al. 1990). If adrenocortical cells are exposed to sub-nanomolar PAF concentrations and to picomolar ACTH concentrations in fluid of the perivascular space of the zona fasciculata and reticularis under immediate hypersensitivity or severe inflammation, cross-regulated cortisol release will be evoked. Although PAF can induce potent corticosteroidogenesis, the process is rapidly desensitized. In the presence of ACTH, PAF has a permissive action on ACTH-induced glucocorticoid secretion and can maintain high concentrations of this antiinflammatory stress hormone. These actions of PAF can ameliorate the severity of dysfunction and suppress the immune responses and/or subsequent immune-mediated inflammation.

\section{Acknowledgements}

The authors thank Mr Yukinori Hirayama for skillful technical assistance. This study was supported in part by grants from the Ministry of Education, Science and Culture, Japan. The use of the Laboratory Animal Center for Biomedical Research at the Medical School of Nagasaki University is gratefully acknowledged. The authors declare that there is no conflict of interest that would prejudice the impartiality of this scientific work.

\section{References}

Aikawa T, Matsumoto I, Hirose T, Morikawa T \& Tsujimoto Y $1986 \mathrm{H}_{1}$ action of histamine on aldosterone and cortisol secretion by perfused dog adrenal. American Journal of Physiology 250 E523-E529.

Aikawa T, Hirose T, Matsumoto I, Morikawa T, Shimada T, Mine Y, Tsujimoto Y \& Tsuji Y 1991 Effect of platelet-activating factor on cortisol and corticosterone secretion by perfused dog adrenal. Lipids 26 1108-1111.

Ali H, Richardson RM, Tomhave ED, DuBose RA, Haribabu B \& Snyderman R 1994 Regulation of stable transfected platelet activating factor receptor in RBL-2H3 cells. Journal of Biological Chemistry 269 24557-24563.

Ali H, Fisher I, Haribabu B, Richardson RM \& Snyderman R 1997 Role of phospholipase $C \beta 3$ phosphorylation in the desensitization of cellular responses to platelet-activating factor. Journal of Biological Chemistry 272 11706-11709.

Baukal AJ, Hunyady L, Catt KJ \& Balla T 1994 Evidence for participation of calcineurin in potentiation of agonist-stimulated cyclic AMP formation by the calcium-mobilizing hormone, angiotensin II. Journal of Biological Chemistry $26924546-24549$

Bernardini R, Calogero AE, Ehrlich YH, Brucke T, Chrousos GP \& Gold PW 1989 The alkyl-ether phospholipid platelet-activating factor is a stimulator of the hypothalamic-pituitary-adrenal axis in the rat. Endocrinology 125 1067-1073.

Caramelo C, Fernandez-Gallardo S, Marin-Cao D, Inarrea P, Santos JC, Lopez-Novoa JM \& Sanchez-Crespo M 1984 Presence of platelet- activating factor in blood from humans and experimental animals. Its absence in anephric individuals. Biochemical and Biophysical Research Communications 120 789-796.

Chuang TT, Sallese M, Ambrosini G, Parruti G \& De Blasi A 1992 High expression of $\beta$-adrenergic receptor kinase in human peripheral blood leukocytes. Journal of Biological Chemistry 267 6886-6892.

Clark AJ \& Cammas FM 1996 The ACTH receptor. Bailliere's Clinical Endocrinology and Metabolism 10 29-47.

Cote M, Guillon G, Payet MD \& Gallo-Payet N 2001 Expression and regulation of adenylyl cyclase isoforms in the human adrenal gland. Journal of Clinical Endocrinology and Metabolism 86 4495-4503.

Ferguson SS 2001 Evolving concepts in G protein-coupled receptor endocytosis: the role in receptor desensitization and signaling. Pharmacological Reviews 53 1-24.

Hirose T 1977 Cortisol and corticosterone productions of isolated adrenal cells in neonatal rabbit. Acta Endocrinologica 84 349-356.

Ishii I \& Shimizu T 2000 Platelet-activating factor (PAF) receptor and genetically engineered PAF receptor mutant mice. Progress in Lipid Research 39 41-82.

Kennelly PJ \& Krebs EG 1991 Consensus sequences as substrate specificity determinants for protein kinases and protein phosphatases. Journal of Biological Chemistry 266 15555-15558.

Kilianova Z, Basora N, Kilian P, Payet MD \& Gallo-Payet N 2006 Human melanocortin receptor 2 expression and functionality: effects of protein kinase $\mathrm{A}$ and protein kinase $\mathrm{C}$ on desensitization and internalization. Endocrinology 147 2325-2337.

Kishimoto A, Mikawa K, Hashimoto K, Yasuda I, Tanaka S, Tominaga M, Kuroda T \& Nishizuka Y 1989 Limited proteolysis of protein kinase C subspecies by calcium-dependent neutral protease (calpain). Journal of Biological Chemistry 264 4088-4092.

Lamberts SWJ, Bons EG \& Zuiderwijk-van der Roest JM 1987 Studies on the mechanism of corticotropin-mediated desensitization of corticosterone secretion by rat adrenocortical cells. Molecular and Cellular Endocrinology $\mathbf{5 2}$ 243-249.

Langlois D, Begeot M, Berthelon M-C, Jaillard C \& Saez JM 1992 Angiotensin II potentiates agonist-induced $3^{\prime}, 5^{\prime}$-cyclic adenosine monophosphate production by cultured bovine adrenal cells through protein kinase C and calmodulin pathways. Endocrinology 131 2189-2195.

Lebrethon M-C, Naville D, Begeot M \& Saez JM 1994 Regulation of corticotropin receptor number and messenger RNA in cultured human adrenocortical cells by corticotropin and angiotensin II. Journal of Clinical Investigation 93 1828-1833.

Martini C, Avalos S \& Vila M 2004 ACTH stimulates the release of alkaline phosphate through Gi-mediated activation of a phospholipase $\mathrm{C}$ and the release of inositolphosphoglycan. Molecular and Cellular Biochemistry 258 191-199.

Pelosin JM, Keramidas M \& Chambaz EM 1991 Production of plateletactivating factor is a component of the angiotensin II-protein kinase C activation pathway in bovine adrenocortical cells. Biochemical Journal 278 29-34.

Penhoat A, Jaillard C \& Saez JM 1989 Corticotropin positively regulates its own receptors and cAMP response in cultured bovine adrenal cells. PNAS 86 4978-4981.

Richardson RM, Haribabu B, Ali H \& Snyderman R 1996 Crossdesensitization among receptors for platelet activating factor and peptide chemoattractants. Journal of Biological Chemistry $27128717-28724$.

Rougeot C, Junier MP, Minary P, Weidenfeld J, Braquet P \& Dray F 1990 Intracerebroventricular injection of platelet-activating factor induces secretion of adrenocorticotropin, beta-endorphin and corticosterone in conscious rats: a possible link between the immune and nervous systems. Neuroendocrinology 51 267-275.

Schwertschlag US \& Whorton AR 1988 Platelet-activating factor-induced homologous and heterologous desensitization in cultured vascular smooth muscle cells. Journal of Biological Chemistry 263 13791-13796.

Sheela Rani CS, Keri G \& Ramachandran J 1983 Studies on corticotropininduced desensitization of normal rat adrenocortical cells. Endocrinology $\mathbf{1 1 2}$ $315-320$. 
Shimada T, Hirose T, Matsumoto I \& Aikawa T 2005 Platelet-activating factor acts on cortisol secretion by perfused guinea-pig adrenals via calciumphospholipid-dependent mechanisms. Journal of Endocrinology 184 381-391.

Stafforini DM, Mclntyre TM, Zimmerman GA \& Prescott SM 2003 Plateletactivating factor, a pleiotrophic mediator of physiological and pathological processes. Critical Reviews in Clinical Laboratory Sciences 40 643-672.

Tomhave ED, Richardson RM, Didsbury JR, Menard L, Synderman R \& Ali H 1994 Cross-desensitization of receptors for peptide chemoattractants. Journal of Immunology 153 3267-3275.

Yamazaki M, Gomez-Cambronero J, Durstin M, Molski TFP, Becker EL \& Sha'afi RI 1989 Phorbol 12-myristate 13-acetate inhibits binding of leukotriene B4 and platelet-activating factor and the responses they induce in neutrophils: site of action. PNAS 86 5791-5794.
Yang H, Koyanagi M, Matsumoto I, Shimada T, Han L \& Aikawa T 1995 Corticosterone secretion in response to serotonin and ACTH by perfused adrenal of normal and athymic nude mice. Life Sciences $\mathbf{5 6}$ 1727-1739.

Yoshida A, Nishikawa T, Tamura Y \& Yoshida S 1991 ACTH-induced inhibition of the action of angiotensin II in bovine zona glomerulosa cells. Journal of Biological Chemistry 266 4288-4294.

Received in final form 25 July 2007

Accepted 7 August 2007

Made available online as an Accepted Preprint

9 August 2007 